\title{
Effect of multienzyme supplementation on weight gain, feed intake, feed efficiency and blood glucose in broiler chickens
}

\author{
R. Balamurugan and D. Chandrasekaran \\ Dept. of Animal Nutrition, Vet. College \& Res. Instt., Tamil Nadu Veterinary \& Animal Sci. Univ., Namakkal, TN, India \\ nutritionbalu@gmail.com; balusuguna@yahoo.com
}

\begin{abstract}
A biological trial in broilers was conducted with seven treatments: T1- Control (without enzyme); T2 - $500 \mathrm{~g} /$ ton NSP hydrolyzing enzyme; T3 -1000 g/ton NSP hydrolyzing enzyme; T4-500 g/ton NSP hydrolyzing enzyme + Phytase, 0.2 per cent DCP reduction; T5-1000 g/ton NSP hydrolyzing enzyme + Phytase, 0.4\% DCP reduction; T6- 500 g/ton NSP hydrolyzing enzyme, $2.5 \%$ reduction of metabolizable energy, crude protein, lysine and methionine; T7 $1000 \mathrm{~g} / \mathrm{ton}$ NSP hydrolyzing enzyme, $5 \%$ reduction of metabolizable energy, crude protein, lysine and methionine. The weight gain $(\mathrm{g})$ recorded in T1, T2, T3, T4, T5, T6 and T7 groups was 1485, 1561, 1600, 1529, 1451, 1417 and 1449 respectively. No significant difference was recorded between the control and enzyme added groups. Significantly $(P<0.01)$ lower feed intake was observed in T6, T2 and T7 compared to T1. The feed efficiency was significantly $(P<0.05)$ better in T2 (1.50) and T3 (1.52) compared to T1 (1.65). A significant or numerical increase in the blood glucose levels was observed in the enzyme supplemented groups compared to the control in before, after $1 \mathrm{hr}$, after $2 \mathrm{hr}$ and after $3 \mathrm{hr}$ feeding periods.
\end{abstract}

Keywords: Broiler, poultry, enzyme, phytase, weight gain, feed, blood glucose.

Introduction

Most of the feed ingredients used in the poultry diet contain non-starch polysaccharides (NSPs) and phytates at different concentrations. The anti nutritional effects of NSPs have been attributed to reduce the digestibility of nutrients (Choct \& Annison, 1990). Birds do not produce enzymes like cellulase, xylanase, phytase etc., required for the digestion of NSPs and phytates. Supplementation of NSPs degrading enzymes and phytase may not only reduce the anti nutritive effects of NSPs and phytates, but also releases some nutrients from these, which could be utilized by the birds. Supplementing multi enzyme in cornsoy based diet to broilers increased body weight comparatively (Kavitha Rani et al., 2003). Keeping this in view, an attempt was made here to study the effect of multi enzyme supplementation to corn soya based diet on the performance of broilers.

\section{Materials and methods}

Feed ingredients, procured locally, were used for the formulation of diet. Pure enzyme preparations viz. cellulase, xylanase, pectinase and phytase were collected and the potency of these enzymes was evaluated by in vitro techniques. The total activity of cellulase, xylanase, pectinase and phytase used in the different experimental groups namely T1-T7 is furnished in the Table 1a and b. Seven experimental starter and finisher diets were formulated (NRC, 1994). The ingredients and nutrient composition of broiler starter and finisher diets are presented in Table $2 \& 3$ a respectively. The NSP hydrolysing enzymes and phytase were included in the rations of treatment groups as follows: T1-
Control (without enzyme); T2 - $500 \mathrm{~g} /$ ton NSP hydrolyzing enzyme; T3-1000 g/ton NSP hydrolyzing enzyme; T4-500 g/ton NSP hydrolyzing enzyme + Phytase, 0.2 per cent DCP reduction; T5-1000 g/ton NSP hydrolyzing enzyme + Phytase, 0.4 per cent DCP reduction; T6-500 g/ton NSP hydrolyzing enzyme, $2.5 \%$ reduction of metabolizable energy, crude protein, lysine and methionine; T7 1000 $\mathrm{g} / \mathrm{ton}$ NSP hydrolyzing enzyme, $5 \%$ reduction of metabolizable energy, crude protein, lysine and methionine.

\section{Experimental design and allocation of birds}

Two hundred and fifty-two Vencobb broiler straight run chicks belonging to a single hatch were used for this experiment. The chicks were wing banded, weighed individually and distributed randomly to the seven experimental diets with three replicates of twelve chicks each. The birds were housed in deep litter pens and reared from day one to six weeks by following uniform standard management practices. The chicks were fed with weighed quantity of experimental diets and they had free access to water. Feed intake was recorded daily, body weight was taken at weekly intervals and weight gain and feed efficiency were worked out.

\section{Blood glucose}

At the end of the sixth week, six birds from each treatment were selected randomly and used for blood glucose estimation. The blood glucose was estimated four times viz. before feeding, after feeding and subsequently at $1 \mathrm{~h}$ interval using electronic instant blood glucose measuring Glucomen Glyco instrument (A.
Research article

CIndian Society for Education and Environment (iSee)
"Broiler improvement" http://www.indjst.org
Balamurugan \& Chandrasekaran Indian J.Sci.Technol. 
Menarini diagnostics, Italy). The data collected on various parameters were statistically analyzed as per the method of Snedecor and Cochran (1989).

\section{Results and discussion \\ Biological experiment}

The effect of enzyme mixtures at 0,500 and $1000 \mathrm{~g} /$ ton of broiler diet was evaluated in terms of weight gain, feed intake, feed efficiency. The data on weight gain, feed intake and feed efficiency of broilers fed the diet supplemented with different levels of enzymes are furnished in the Table $3 b$.

\section{Weight gain}

The mean body weight gain of $\mathrm{T} 1, \mathrm{~T} 2, \mathrm{~T} 3, \mathrm{~T} 4, \mathrm{~T} 5$, T6 and T7 experimental groups was $1485.00,1561.89$, $1600.74,1529.10,1451.33,1417.13$ and $1449.38 \mathrm{~g}$ respectively. Though a numerical increase in body weight gain was observed in enzyme added groups T2, T3 and T4, which may be due to the enhanced hydrolysis of NSPs and a decline in body weight gain was noticed in experimental groups T5, T6 and T7. The slight reduction in the addition of inorganic phosphorus in the T5 group and reduction of protein and energy by 2.5

Table 1a. Cellulase, xylanase, pectinase and phytase activity $(\mathrm{IU} / \mathrm{g})$ of pure enzyme preparations

\begin{tabular}{|l|l|l|l|}
\hline $\begin{array}{c}\text { Cellulase } \\
\text { activity }\end{array}$ & $\begin{array}{c}\text { Xylanase } \\
\text { activity }\end{array}$ & $\begin{array}{l}\text { Pectinase } \\
\text { activity }\end{array}$ & $\begin{array}{l}\text { Phytase } \\
\text { activity }\end{array}$ \\
\hline 4394.18 & 6950.45 & 3250.42 & 37.59 \\
855.44 & 92341.33 & 2591.89 & 37.52 \\
60.68 & 798.22 & 5247.22 & 56.19 \\
105.35 & 250.43 & 162.35 & 7585.08 \\
\hline
\end{tabular}

Table 1b. Total enzyme activity used in the broiler trial (IU/kg feed)

\begin{tabular}{|l|c|c|c|c|c|}
\hline \multicolumn{1}{|c|}{ Activity } & T1 & T2 \& T6 & T3 \& T7 & T4 & T5 \\
\hline Cellulase & Nil & 199.6 & 402.82 & 199.6 & 402.82 \\
Xylanse & Nil & 1009.3 & 2020.02 & 1009.3 & 2020.02 \\
Pectinase & Nil & 299.62 & 600.37 & 299.62 & 600.17 \\
Phytase & Nil & 3.39 & 6.80 & 198.43 & 399.86 \\
\hline
\end{tabular}

and 1.63 respectively. There was a significant $(P<0.01)$ differences observed in T2 and T3 groups when compared to control. Among the enzyme treated groups T7 was significantly $(P<0.01)$ higher than T2 and T3 groups and T6 was significantly higher than T2. Zanella et al. (1999) observed that addition of Avizyme to corn-soybean based broiler diet improved the feed efficiency by 2.2 per cent. Similar results were also reported (Kavitha Rani et al., 2003; Singh et al., 2003; Wu et al., 2004).

and $5 \%$ in the $\mathrm{T} 6$ and $\mathrm{T} 7$ groups respectively could be the possible reason for the decline in body weight gain when compared to the control. Zanella et al. (1999) in their study found that supplementation of Avizyme $(0.1 \%)$ to cornsoybean based diet had improved the body weight gain by $1.9 \%$ over that of control.

\section{Feed intake}

The mean feed intake of birds fed diets to T1, T2, T3, $\mathrm{T} 4, \mathrm{~T} 5, \mathrm{~T} 6$ and $\mathrm{T} 7$ was 2459, 2347, $2444,2432,2441$, 2296 and $2369 \mathrm{~g}$ respectively.

A

significant $(P<0.01)$ reduction in feed intake was noticed in
Table 3a. Ingredient and nutrient composition of broiler finisher diet (\% DM basis)

\begin{tabular}{|l|c|c|c|c|c|c|c|}
\hline \multirow{2}{*}{ Ingredients (\%) } & \multicolumn{7}{c|}{ Treatments } \\
\cline { 2 - 8 } & T1 & T2 & T3 & T4 & T5 & T6 & T7 \\
\hline Maize & 54.4 & 54.4 & 54.4 & 54.7 & 55.2 & 58.3 & 62.2 \\
Soya & 37.3 & 37.3 & 37.3 & 37.3 & 37.2 & 35.4 & 33.5 \\
Rice bran oil & 5.7 & 5.7 & 5.7 & 5.6 & 5.4 & 3.7 & 1.7 \\
Dicalcium phosphate & 1.3 & 1.3 & 1.3 & 1.1 & 0.9 & 1.3 & 1.3 \\
Calcite & 1.3 & 1.3 & 1.3 & 1.3 & 1.3 & 1.3 & 1.3 \\
$\begin{array}{l}\text { DL Methionine (g/100kg) } \\
\text { Additives }\end{array}$ & 150 & 150 & 150 & 150 & 150 & 146.2 & 142.5 \\
$\begin{array}{l}\text { supplements } \\
\text { (g/100kg) }\end{array}$ & 685 & 685 & 685 & 685 & 685 & 685 & 685 \\
\hline
\end{tabular}

\section{Blood glucose}

The effect of enzyme supplementation on the blood glucose level of broilers is presented in Table 4. A significant or numerical increase in the blood glucose levels was observed in the enzyme supplemented groups compared to the control in all the time periods. The T3 (241.5mg/dL) recorded the highest level followed by $\mathrm{T} 2$ (231.8), T6 (228.2), T5 (208.5), T4 (204.7), T7 (188.7) and T1 (174) before feeding. One hour after feeding T5 (269.8) recorded the highest followed by T3 (261.8), T2
Research article

(CIndian Society for Education and Environment (iSee)
"Broiler improvement" http://www.indjst.org
Balamurugan \& Chandrasekaran Indian J.Sci.Technol. 
(256.8), T7 (254.7), T4 (253.2), T6 (242.3) and T1 (238.5). Two hours after feeding the highest value was observed again in T5 (285) followed by T3 (282), T4 (278.8), T2 (274.3), T6 (267.7), T7 (258.5) and T1 (252.2). Three hours after feeding it was again T5 (280.5) which recorded the highest value, followed by T3 (271.5), T4 (264), T2 (262.5), T7 (251), T6 (244) and T1 (240). soyabean meal fed to broilers. Br. Poult. Sci. 43, 5463.

4. NRC (1994) Nutrient requirements of poultry. $9^{\text {th }}$ edn. National Academy Press, Washington, D.C.

5. Sikka SS and Chawla JS (2002) Influence of enzyme supplementation of wheat and rice kani based diets on the performance of broilers. Anim. Nutri. Feed Tech. 2, 11-18.

Table 3b. Effect of enzyme supplementation on weight gain, feed intake and feed efficiency in broiler chickens (0-6 weeks)

\begin{tabular}{|c|c|c|c|}
\hline Treatments & Weight gain $(\mathrm{g})^{*}$ & Feed intake $(\mathrm{g})^{* *}$ & Feed efficiency $^{*}$ \\
\hline T1 & $1485.00^{\mathrm{abcd}} \pm 35.76$ & $2459.19^{\mathrm{d}} \pm 20.06$ & $1.65^{\mathrm{c}} \pm 0.04$ \\
T2 & $1561.89^{\mathrm{de}} \pm 24.35$ & $2347.83^{\mathrm{ab}} \pm 33.08$ & $1.50^{\mathrm{a}} \pm 0.01$ \\
T3 & $1600.74^{\mathrm{de}} \pm 32.46$ & $2444.70^{\mathrm{cd}} \pm 13.61$ & $1.52^{\mathrm{ab}} \pm 0.01$ \\
T4 & $1529.10^{\mathrm{bcde}} \pm 35.60$ & $2432.36^{\mathrm{bcd}} \pm 28.64$ & $1.59^{\mathrm{abc}} \pm 0.02$ \\
T5 & $1451.33^{\mathrm{abc}} \pm 47.28$ & $2441.80^{\mathrm{cd}} \pm 9.25$ & $1.58^{\mathrm{abc}} \pm 0.03$ \\
T6 & $1417.13^{\mathrm{a}} \pm 46.99$ & $2296.54^{\mathrm{a}} \pm 14.93$ & $1.62^{\mathrm{bc}} \pm 0.04$ \\
T7 & $1449.38^{\mathrm{ab}} \pm 44.72$ & $2369.21^{\mathrm{abc}} \pm 18.02$ & $1.63^{\mathrm{c}} \pm 0.03$ \\
\hline
\end{tabular}

Each value is a mean of three observations *Means with at least one common superscript in a column do not differ significantly $(P<0.05)$. *Means with at least one common superscript in a column do not differ significantly $(P<0.01)$

Addition of enzyme at $1 \mathrm{~kg} / \mathrm{ton}$ of feed was able to increase marginally the blood glucose in all the time periods, similarly higher addition of phytase was also able to slightly enhance the blood glucose levels. The results indicated multi enzyme supplementation to corn soy based diets though do not significantly increase the weight gain, but significantly reduces the feed intake, improve the feed efficiency and increase the blood glucose release.
6. Singh PK and Khatta VK (2003) Effect of phytase supplementation on the performance of broiler chickens fed wheat based diets. Indian J. Anim. Nutr., 20(1), 57-62.

7. Snedecor GW and Cochran WC (1989) Statistical Methods. $8^{\text {th }}$ edn. lowa State Univ. Press, Ames, lowa.

8. Wu YB, Ravindran V, Thomas DG, Birtles MJ and Hendriks WH (2004) Influence of phytase and xylanase, individually or in combination on performance, apparent metabolisable energy, digestive tract measurements and gut morphology in broilers fed wheat based diets containing adequate level of phosphorus. Br. Poult. Sci. 45, 76-84.

9. Zanella I, Sakomura NK, Silversides FG, Fiqueirdo A and Pack M (1999) Effect of enzyme supplementation of broiler diets based on corn and soyabeans. Poult. Sci. 78, 561-568.

Table 4. Effect of different levels of enzyme supplementation on blood glucose level in broiler chickens

\begin{tabular}{|c|c|c|c|c|}
\hline $\begin{array}{c}\text { Treatment } \\
\text { groups }\end{array}$ & $\begin{array}{c}\text { Before feeding blood } \\
\text { glucose leve }^{* *}\end{array}$ & $\begin{array}{c}\text { After } 1 \mathrm{hr} \text { feeding blood } \\
\text { glucose level }^{*}\end{array}$ & $\begin{array}{c}\text { After } 2 \mathrm{hr} \text { feeding blood } \\
\text { glucose level }^{*}\end{array}$ & $\begin{array}{c}\text { After } 3 \mathrm{hr} \text { feeding blood } \\
\text { glucose level }^{*}\end{array}$ \\
\hline T1 & $174.00^{\mathrm{a}} \pm 4.71$ & $238.50^{\mathrm{a}} \pm 3.60$ & $252.16^{\mathrm{a}} \pm 8.75$ & $240.00^{\mathrm{a}} \pm 7.30$ \\
T2 & $231.83^{\mathrm{cd}} \pm 7.18$ & $256.83^{\mathrm{bc}} \pm 6.01$ & $274.33^{\mathrm{bc}} \pm 5.81$ & $262.50^{\mathrm{abc}} \pm 5.53$ \\
T3 & $241.50^{\mathrm{d}} \pm 13.73$ & $261.83^{\mathrm{c}} \pm 9.60$ & $282.00^{\mathrm{c}} \pm 8.91$ & $271.50^{\mathrm{bc}} \pm 13.57$ \\
T4 & $205.66^{\mathrm{abc}} \pm 6.29$ & $253.16^{\mathrm{abc}} \pm 6.57$ & $278.83^{\mathrm{bc}} \pm 5.41$ & $264.00^{\mathrm{abc}} \pm 7.43$ \\
T5 & $208.50^{\mathrm{bcd}} \pm 6.44$ & $269.83^{\mathrm{c}} \pm 6.72$ & $285.00^{\mathrm{c}} \pm 6.16$ & $280.50^{\mathrm{c}} \pm 5.46$ \\
T6 & $228.16^{\mathrm{cd}} \pm 6.35$ & $242.33^{\mathrm{ab}} \pm 3.04$ & $267.66^{\mathrm{abc}} \pm 4.70$ & $244.00^{\mathrm{a}} \pm 8.56$ \\
T7 & $188.66^{\mathrm{ab}} \pm 12.60$ & $254.66^{\mathrm{abc}} \pm 5.04$ & $258.50^{\mathrm{ab}} \pm 10.92$ & $251.00^{\mathrm{ab}} \pm 11.18$ \\
\hline
\end{tabular}

Each value is a mean of six observations. *Means with at least one common superscript in a column do not differ significantly $(P<0.05)$. ${ }^{* *}$ Means with at least one common superscript in a column do not differ significantly $(P<0.01)$

\section{References}

1. Choct M and Annison G (1990) Anti-nutritive activity of wheat pentosans in broiler diets. Br. Poult. Sci. 31, 811-821.

2. Kavitha Rani B, Jayashree Desai, Deepika Reddy and Radhakrishna PM (2003) Effect of supplementation of enzymes for non starch polysaccharides in corn-soya diet in broilers. Indian J. Anim. Nutr. 20(1), 63-69.

3. Kocher A, Choct M, Porter MD and Broz J (2002) Effects of feed enzymes on nutritive value of

Research article

CIndian Society for Education and Environment (iSee)
"Broiler improvement" http://www.indjst.org
Balamurugan \& Chandrasekaran Indian J.Sci.Technol. 